\title{
9 Innovations of the 21st Century in the Management of Iranian Salt-Affected Lands
}

\author{
Zeinab Hazbavi and Mostafa Zabihi Silabi
}

\section{CONTENTS}

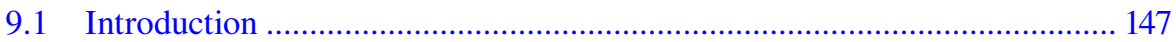

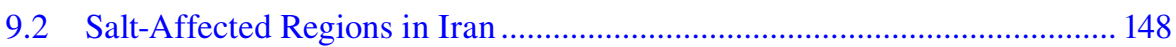

9.3 Management Strategies for Salt-Affected Area........................................... 150

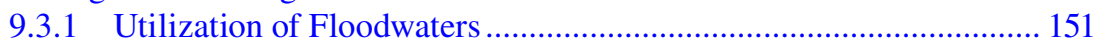

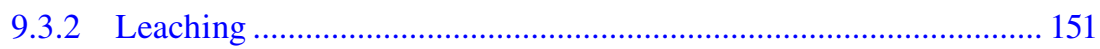

9.3.3 Reusing Drainage Waters ……………………............................. 152

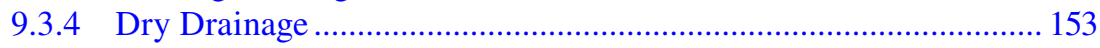

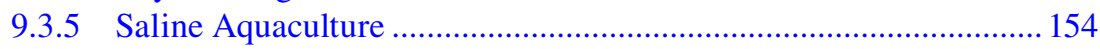

9.3.6 Halophytes as Salt-Tolerant Crops ................................................... 155

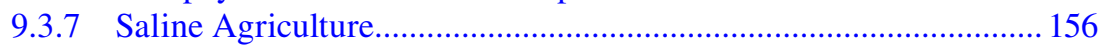

9.3.8 Executive Operations around Lake Urmia ....................................... 159

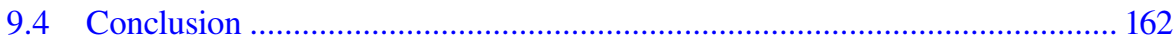

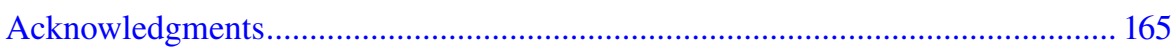

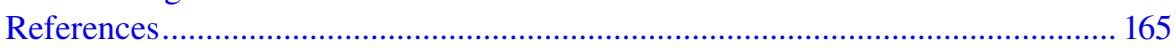

\subsection{INTRODUCTION}

All life on Earth is anchored by soil and sustained by water. The European Commission (EC 2006) has highlighted seven functions of soil including biomass production (viz., agriculture and forestry), the storing, filtering and transforming of nutrients, substances and water, as a pool for biodiversity (such as in habitats, species and genes), a physical and cultural environment for humans and human activities, a source of raw material, acting as a carbon pool and as an archive of geological and archaeological heritage. Water is the most widespread substance that plays a crucial role both for the environment and in human life (Stec 2020). However, a range of natural and human-based factors are affecting soil and water functions (Sadeghi et al. 2019; Hazbavi et al. 2020), making them saline in many parts of the world. About 1125 Mha of the Earth's surface in more than 100 countries is affected by salinity, and these numbers are continually growing (Ivushkin et al. 2019). The salinity 
problem has been threatening sustainable land development and is one of the significant causes of land degradation from ancient times until now. Salinity is a universal concern for the 21st century because of its accelerating impact on the quality of life, particularly food security. The Middle East, including Iran (i.e., the Islamic Republic of Iran), has significant areas of salt-affected soils (Ivushkin et al. 2019). After India and Pakistan, Iran is one of the most vulnerable countries to salinity (Moameni 2011). Numerous studies have been done to assess, monitor, evaluate, map and combat the salinity of soil and water resources in Iran (e.g., Tavousi et al. 2018; Hazbavi et al. 2019; Salehi and Dehghani 2019; Bagheri 2019; Fathizad et al. 2020; Mahmoodi-Eshkaftaki and Rafiee 2020). The present review summarizes Iranian activities in the salinity area over the first two decades of the 21st century. This research presents a useful road map for future policy making at regional, national and global levels.

\subsection{SALT-AFFECTED REGIONS IN IRAN}

Iran is located in West Asia; it has an area of $164.8 \times 10^{6}$ ha $\left(163.6 \times 10^{6}\right.$ ha land and $1.2 \times 10^{6}$ ha water bodies) (Qadir et al. 2008). Iran is home to several salt diapirs, lakes and marshes, including Lake Urmia, one of the largest hypersaline lakes in the world. The main soil types of Iran are Xerosols, Arenosols, Regosols, Solonchalks and Lithosols (Siadat 1998). The mass of saline waters in the country is also significant. Shiati (1998) reported that of the country's 100 billion $\mathrm{m}^{3}$ of water resources, about 11 billion $\mathrm{m}^{3}$ have a salinity of over $1500 \mathrm{mg} \mathrm{L}^{-1}$. Several rivers of the south, southwest and central parts of the country are saline (Ranjbar and Pirasteh-Anosheh 2015).

Figure 9.1 shows the spatial variation of soil salinity in Iran (Banie 2001). Soil salinity hotspots occur on the Khuzestan Plain, central plateau, southern coastal plain and in the inter-mountain valleys. In addition, about 50\% of irrigated lands fall into different categories of salt-affected soils. The salinization of land and water resources in Iran has been the result of natural and anthropogenic conditions. The arable soils of Iran show some evidence of a long history of anthropological interference. Around $11 \%$ of Iran is cultivated land, which also includes 8.1 Mha of irrigated agriculture (ICID 2002; Qadir et al. 2008). The latest assessments have shown a 6\% increase in the total cultivated area since the late 1990s (Qadir et al. 2008). Average crop yields are higher with irrigation than under dry-farming conditions, and this has led to a 3.8\% expansion of irrigated farming systems between the 1980s and early 1990s. During the second national development plan (1993-98), there was an increase of $0.5 \times 10^{6}$ ha in irrigated land which had consequences for salinization. The nonexistence of appropriate water management tools resulted in the low effectiveness of water use; the overall efficiency was $\sim 30 \%$. The level of land affected by salinity also varies in the different provinces of the country. In Khuzestan and Fars provinces, salinity accounts for 32.9 and $16.4 \%$ of the land area, respectively; but in East Azarbaijan Province, only 1.36\% is affected. Figure 9.2 shows a general view of the soil salinity status in irrigated lands of Iran. Soils with $\mathrm{EC}_{\mathrm{e}}$ values of $0-4,4-8$, 8-16, 16-32 and more than $32 \mathrm{dS} \mathrm{m}^{-1}$ are, respectively, designated as soils with no salinity, slight, moderate, strong and very strong salinity (World Bank 2005). 


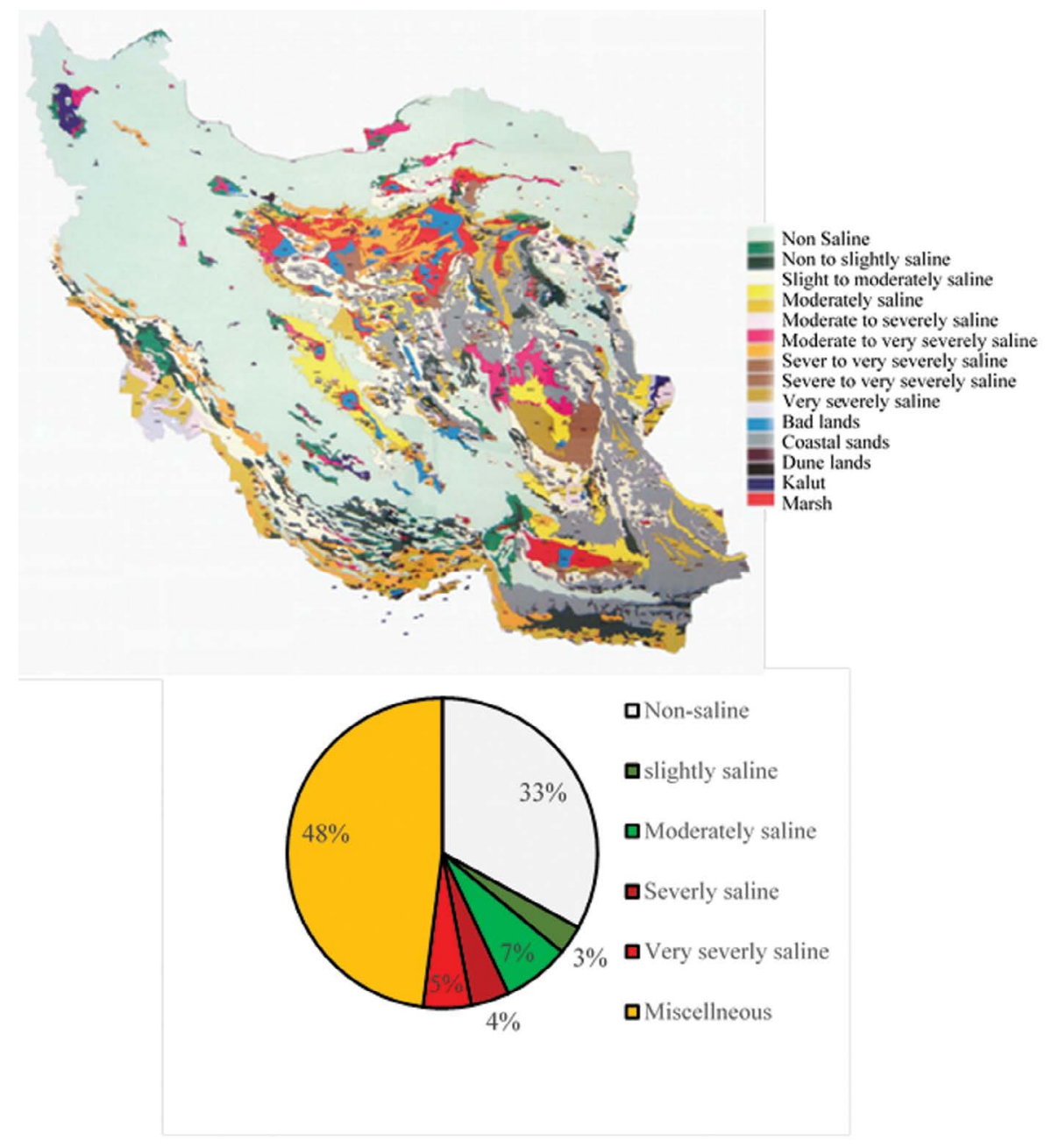

FIGURE 9.1 Spatial variation of salinity in Iran. (Source: Banie 2001.)

The oldest report on salinity in Iran comes from Dewan and Famouri (1964) who indicated that saline and alkaline soils accounted for about $12.5 \%$ of the country's total area. Other reports have referred to salinity accounting for 25-27 Mha (15-17\% of total land area) (Sayyari and Mahmoodi 2002) and 34 Mha (20.6\% of the total land area), including 25.5 Mha of low to medium salinity and 8.5 Mha of high salinity (Moameni et al. 1999). Of the total of 6.8 Mha of salt-affected agricultural land, about 4.3 Mha have only salinity limitations whereas the other 2.5 Mha have other additional limitations including a susceptibility to erosion and a shallow depth to water table. In most salt-affected soils in agricultural areas, the depth to the water table is deeper than the root zone. (Areas in which the depth to water-table falls within the root zone are only $\sim 8.4 \%$ of the total salt-affected 


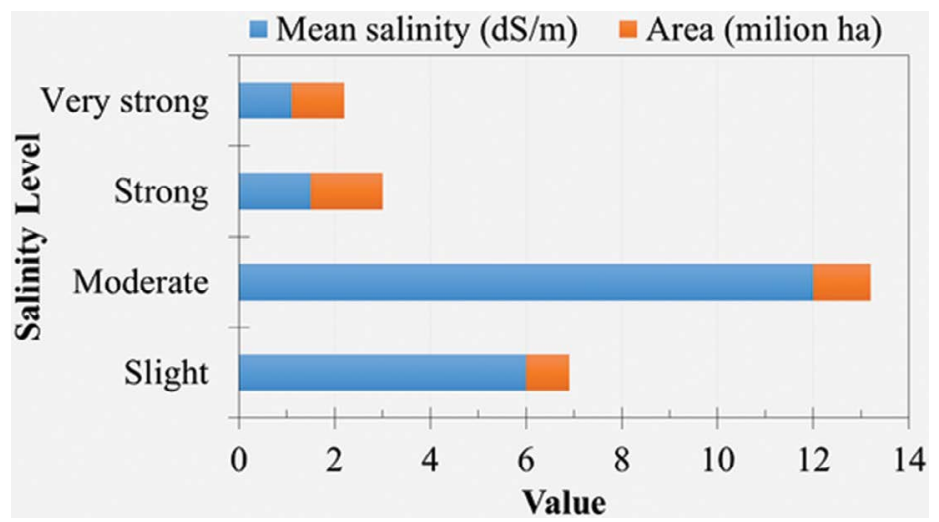

FIGURE 9.2 Soil salinity levels of irrigated lands of Iran. (Source: World Bank 2005.)

agricultural lands). This suggests that the reclamation of salt-affected lands is technically practical and economically viable (Moameni 2011). In another study, the total area of irrigated land in Iran was 7.3 Mha, and the total area of arable land with varying degrees of salinity of the soil, water, or both was estimated to be 3.3 Mha (Banaei et al. 2004).

Most recently, Moameni (2011) has assessed the geographical distribution and salinity levels of Iran's soils. The results showed that 6.8 Mha of agricultural land have soils with different salinity levels. Of this, about 3.4 Mha have no restrictions other than salinity, and about 2.5 Mha also have additional restrictions caused by variation in texture, depth, drainage coefficient, poor permeability and high risk of erosion; about 0.5 Mha $(8.4 \%)$ have shallow groundwater problems in the root zone (Moameni 2011). The salinization of land resources in Iran has been the consequence of both natural and human activities (Siadat et al. 1997; FAO 2000; Qadir et al. 2008).

\subsection{MANAGEMENT STRATEGIES FOR SALT-AFFECTED AREA}

Different research institutes and universities have conducted research on the management of soil and water salinity in Iran for more than half a century. There are many effective ways for improving salt-affected lands, such as water leaching, drainage water management, soil management, chemical remediation, phytoremediation, growth and genetic improvement of salt-tolerant crops and use of irrigation scheduling practices. The first field works to evaluate different techniques for improving salt-affected soils were started in the 1970s by the Soil and Water Research Institute (SWRI; www.swri.ir). The Agriculture Biotechnology Research Institute of Iran (ABRII) was established in 1999 to develop and use modern agricultural technologies to solve agricultural problems, improve food security and community nutritional health and protect essential resources and environmental substrates for sustainable development. This institute carried out a comprehensive project on Salicornia to produce forage, oil and other biological sub-products and mitigate 
against dust storms. In addition, numerous soil and water scientists, conservationists and ecologists were engaged in projects focused on salinity mitigation, control and management. In 2000, the National Salinity Research Center (NSRC; www.nsrc. areeo.ac.ir) was established to focus on all research activities in the field of salinity. This center now tackles diverse aspects of soil and water salinity problems in different agro-ecological regions. The main areas included in salinity management projects have been in Yazd, Golestan, Fars, Khurasan, Khuzestan, Markazi, Hormozgan (Bushehr), Moghan, Azerbaijan, Esfahan and Qom provinces (Heydari 2019).

\subsubsection{Utilization of Floodwaters}

The use of seasonal floods in agriculture and horticulture has a long history in Iran and elsewhere in the world. Sabzevar and Khosroshahi (2010) investigated the effects of low-quality floodwater on the desert area of the KaleShoor River, Sabzevar. They concluded that flood irrigation was able to leach gypsum from the root zone into deeper soil layers. This approach was also of benefit in restoring and improving pastures in different areas. By creating a diversion bar on the margin of the BarAbad Desert in Sabzevar, rier, seasonal floods of the KaleShoor River with a salinity of 7-14 dS m ${ }^{-1}$ were used to revitalize and modify pastures revegetated with Atriplex canescens through irrigation once a year. With this treatment, forage production increased from 10 to more than $700 \mathrm{~kg} \mathrm{ha}^{-1}$. This practice allowed for the development of dairy farming and decreased rural migration. Though droughts and environmental conditions have caused some parts to be dry in some years, the projected area was increased by more than 3000 ha over 10 years, and species such as Nitraria schoberi, Seidlitzia rosmarinus and Haloxylon spp. were cultivated (Filehkesh and Hashemi Nezhad 2017). Floodwater spreading and floodwater farming have also improved crop production in Africa (Asch and Woperei 2001), America (Nabhan 1979), China (Guo et al. 2008; Seydehmet et al. 2019) and Spain (Hooke and Mant 2002).

\subsubsection{Leaching}

The use of soil leaching can decrease the adverse effects of salt on crop establishment (Heydari 2019). This approach is especially relevant to soils with high levels of clay or hardpans in the Khuzestan, Isfahan and Tabriz plains. Khoshgoftarmanesh and Shariatmadari (2002) did a ground survey to explore the leachability of saline soils in Qom Province. Soils initially had $\mathrm{EC}_{\mathrm{e}}$ values of 67.1 and $54.7 \mathrm{dS} \mathrm{m}^{-1}$ in the surface and sub-surface layers; leaching water came from rainfall and snowmelt. With leaching after one year, $\mathrm{EC}_{\mathrm{e}}$ values in soil were less than $\mathrm{EC}_{\mathrm{w}}$ of the irrigation water. Severe symptoms of delayed germination and the burning of leaf margins were observed in control plots without leaching, whilst improved crop yields were reported for plots treated with salt leaching.

Moameni and Stein (2002) and Qadir et al. (2008) concluded that incorporating leaching with an improved drainage system could sustainably ameliorate most of the soils of Iran. Azadegan (2008) noted the benefits of leaching, drainage and sulfur application in improving the quality of pistachio orchards growing on saline soils in Garmsar County, Semnan Province. Bazzaneh and Rezaei (2017) evaluated 
the leaching of saline-sodic soils using different levels of pure and acidic water in some parts of the Mahabad Plain (West Azerbaijan Province) irrigation and drainage network. In this study, to evaluate the possibility of modification of saline-sodic soils, different treatments with pure and acidified waters at three levels of application $(25,50$ and $75 \mathrm{~cm})$ were repeated in a randomized complete block design in three days. The results showed that the lowest and highest percentages of salinity and alkalinity improvement were related to the application of $25 \mathrm{~cm}$ pure water or $75 \mathrm{~cm}$ acidic water with 24.7 and $41.2 \%$ decreases in mean values of exchangeable sodium and 25.9 and $69.0 \%$ decreases in $\mathrm{EC}_{\mathrm{e}}$ values compared to initial soil conditions, respectively.

The international scientific literature suggests that the leaching requirement varies with the level of salinity in the irrigation water and with crop salt tolerance (Kolahchi and Jalali 2007; Mostafazadeh-Fard et al. 2009; Heydari 2019). In other regions of the world, this technique has been studied and applied to achieve varying target outcomes. For instance, Corwin et al. (2007) described the use of steady-state and transient models to characterize leaching requirements for soil salinity control. Ning et al. (2020) evaluated the irrigation water salinity and leaching fraction on the water productivity of barley, bean, wheat and maize crops in China. The required leaching fraction depended on the salt tolerance of the crop and the salinity of the irrigation water. Despite the advantages of leaching, its application has not always been successful or accepted by decision-makers. Ning et al. (2020) noted that the risk of environmental contamination might be increased due to the leaching of pesticides, nutrients and trace elements. Furthermore, it is worth noting that drought and water crises exist in many regions because there is limited access to freshwater. Using this method for salinity abatement may, therefore, gain less attention in the future.

\subsubsection{Reusing Drainage Waters}

The use of drainage and saline waters for agricultural irrigation or other objectives involves several management methods (Nasrollahi et al. 2017). Choosing the appropriate method for releasing or reusing drainage waters mainly depends on the quality of the water concerned. Water with an $\mathrm{EC}_{\mathrm{w}}$ of up to $8 \mathrm{dS} \mathrm{m}^{-1}$ can be used for the irrigation of salt-resistant crops such as barley, sugarbeet, rapeseed and cotton (Homaei 2003). Nasrollahi et al. (2017) examined the effects of drip irrigation using saline water on corn crops at the research farm-scale, at Shahid Chamran University in Khuzestan Province. Drip irrigation with proper management appeared suited to the reuse of vast quantities of drainage water. Sharifipour et al. (2017) investigated the reuse of saline drainage water using a system dynamics analysis tool (Vensim) in the western part of the Karun River, a region where the land is $~ 99 \%$ saline. Their results showed that, for at least the next 20 years, the quality of drainage water released from south Karkhe and west Karun River Basins will not be suitable for the cultivation of saline resistant crops except for sugarcane. However, the drainage effluent from these areas will be suitable for developing vegetation in rangelands. The most critical challenge in controlling dust production in the south of Khuzestan Province is the supply of water to these areas; vegetation development with these effluents will be possible shortly. 
Rhoades and Dinar (1991) conducted a study in the United States on the reuse of agricultural drainage water to increase water supplies for irrigation. They first intercepted and isolated the drainage water from the good-quality water; this water was then reused for the irrigation of suitably salt-tolerant crops, decreasing the volume of secondary drainage water that needed to be disposed of. Hussain et al. (2019) have reviewed the use and management of non-conventional water resources such as saline water, wastewater and graywater for the rehabilitation of the arid and semiarid MENA (the Middle East and North Africa) regions. They concluded that the recovery of marginal and saline degraded lands via appropriate planning and the sustainable use of different sources of non-conventional water could be an economic and environmental investment.

\subsubsection{Dry Drainage}

Dry drainage refers to the planting of irrigated crops in slightly higher areas adjacent to lower fallow land. "Drainage" can occur if the irrigation results in the development of a shallow water-table, but the water actually evaporates from the adjacent fallow area (Figure 9.3). This method, initially introduced by Gowing and Wyseure (1992) can contribute to the removal of excess water and salt from irrigated land and control soil salinity (Wu et al. 2009; Mostafazadeh-fard and Ghasemi 2016). Dry drainage is an appropriate alternative management tool where artificial drainage is not applicable (Wu et al. 2009). Dry drainage has been recently introduced into some regions of Iran such as Tehran and Isfahan as a novel method for the drainage of agricultural areas. This method has potential for arid and semi-arid areas with a shallow water-table and high potentials for evaporation

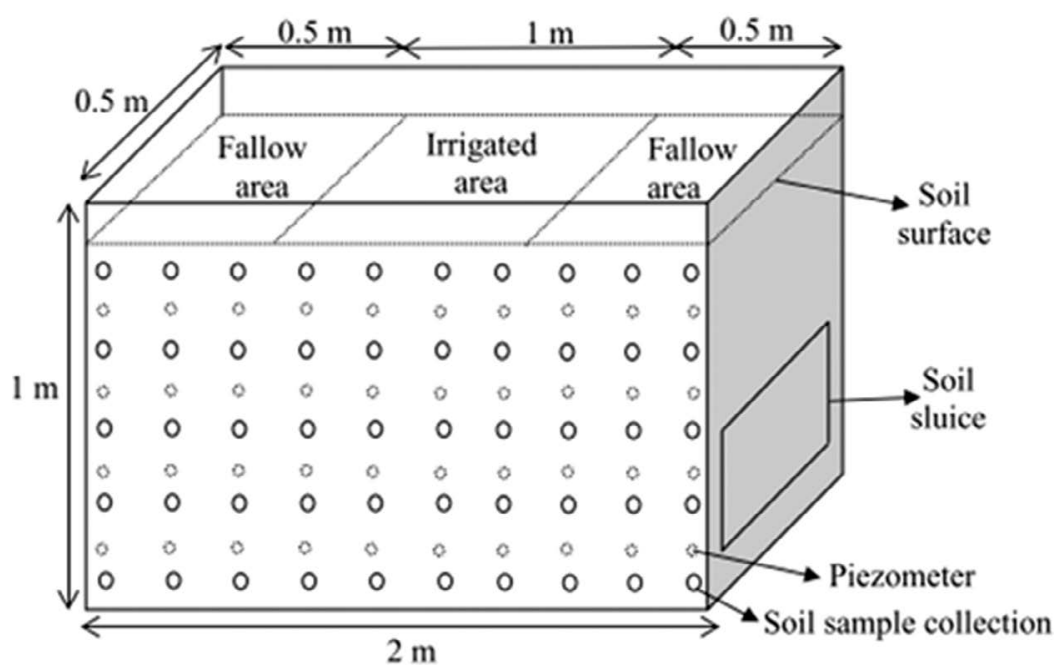

FIGURE 9.3 Diagram of the dry drainage simulation model. (Source: Ansari et al. 2017.) 
and capillary rise (Soltani et al. 2017; Ansari et al. 2017, 2019). Mostafazadeh-Fard and Ghasemi (2016) tested the effects on dry drainage of depth to water-table, irrigation water salinity, groundwater salinity and soil salinity. Their results indicated a significant reduction in soil salinity in a study area without polluting surface or underground water. This technology has potential for areas that have an impermeable layer near the soil surface and a hydraulic gradient between the irrigated and non-irrigated (fallow) fields.

In China Wang et al. (2019) also investigated the efficiency of the dry drainage method for soil salinity control at a field location over five years (2007-2011). The established dry drainage system played an important role in draining excess water and salt. Konukcu et al. (2006) evaluated the application of dry drainage in the Lower Indus Basin in Pakistan. This area was characterized by shallow saline groundwater, intensive irrigation and high evaporation. The results showed a satisfying balance between water and salt when the cropped area and sink area were approximately equal, and the water-table depth was around $1.5 \mathrm{~m}$.

\subsubsection{Saline Aquaculture}

Nakhaei et al. (2018) conducted a project to use brackish and saline water resources in Kerman Province from 2008 to 2009 in the city of Ravar-Shahrbabak-SirjanZarand and Rafsanjan. They concluded that the culture of rainbow trout, sturgeon, seabream, milkfish, carp, tilapia and artemia are feasible. Typical pictures of the artemia ponds established during the project are shown in Figure 9.4. In the study region, there are many saline water sources which are not suitable for agriculture, drinking or industry. In addition, with the movement of salty water towards freshwaters, the volume of freshwater has also been reduced. The results of this research showed that the salinity of these waters varies from 5.12 to 96 $\mathrm{dS} \mathrm{m}{ }^{-1}$. Regardless of source, the water ranged in temperature (lowest to highest) from 13.5 to $24.5^{\circ} \mathrm{C}$, and the $\mathrm{pH}$ varied from 6.8 to 8.6. Manaffar et al. (2020) studied the reproduction and life span characterization of Artemia urmiana in Lake Urmia at five sampling stations of Heydarabad, Golmankhaneh, Bari, Kabodan and Eslami. The different environmental conditions at the various locations in the lake caused differences in the growth, survival and reproduction of the fish; best reproduction and life span occurred at the Bari, Golmankhaneh and Heydarabad locations.

At a global level, aquaculture provides more than $50 \%$ of food needs, and is estimated to expand to about $93.2 \times 10^{9} \mathrm{~kg}$ by 2030; aquaculture will therefore be a leading food supply source (Hawrot-Paw et al. 2020). To this end, several technologies are developing to increase saline aquaculture production. For instance, in Poland Hawrot-Paw et al. (2020) used a growth medium containing Chlorella minutissima and verified its efficiency in saline aquaculture. In India Debroy et al. (2020) cultured shrimp (Litopenaeus vannamei) as a potential species for sustainable production in inland saline waters. High growth rate, tolerance to high stocking density, tolerance to fluctuations in temperature and salinity, utilization of a low protein diet, a high meat yield, easy spawning and high disease resistance were noted as advantages of this shrimp for saline aquaculture. 


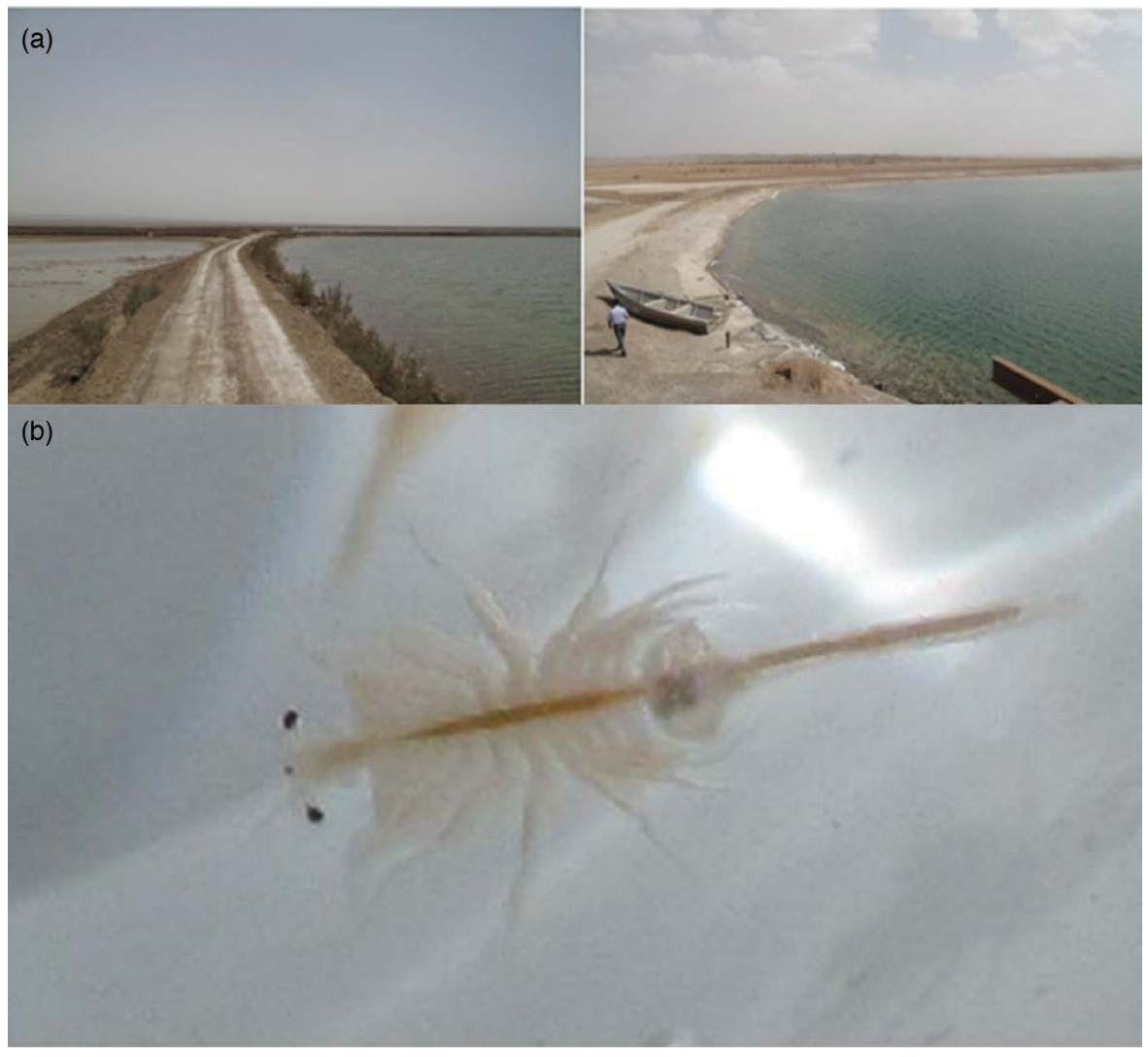

FIGURE 9.4 Artemia culture using saltwater (a) and a sample of the cultured artemia (b). (Source: Nakhaei et al. 2018.)

\subsubsection{Halophytes as Salt-Tolerant Crops}

The importance of salt-tolerant plant species for the restoration of salt-affected soils has been evaluated in several parts of the country (Koocheki 1996). Halophytes are important species in the rangeland communities of salt-affected areas. While close interactions have been recognized between livestock and halophytic communities as forages, these linkages have not been sufficiently employed at scale. Utilizing halophytes for various goals (e.g., for fodder, manufacturing and domestic applications) has been well-received by indigenous people. Qadir et al. (2008) reported that 16 halophytic plant families contain $92 \%$ of the halophytic species identified in the country. Atriplex is a prospective and economic forage source and is an agent in combating desertification in arid lands (Koocheki 1996; 2000).

The physiological characteristics of nine halophytic forage plants were evaluated at the Research Station of Chah Afzal, Yazd in 2011-2012. There were significant physiological differences between species, which may be related to their ability to produce forage. Amongst the species studied, Kochia indica, Sesbania aculeata and 
Atriplex halimus were selected as superior species due to their higher forage production and low ash, sodium and chloride concentrations (Banakar et al. 2012). Soleimani and Najafifar (2017) investigated the effects of several hand-planted halophytes on the salinity and sodium in soils in southeastern Fars Province. Their results showed that regardless of the depth and distance apart of the plant species, the $\mathrm{EC}_{\mathrm{e}}$ of the soil in the shade of plants was significantly higher than outside the shade. The effects were more significant at $0-10 \mathrm{~cm}$ than at $10-40 \mathrm{~cm}$ depth. Various research has also been conducted on the nutritional value of halophytes, including Gamanthus gamocarpus, Petrosimonia glauca, Salsola crassa, Halotis occulta, Halocaris sulphurea, Alhagi sp., Gundelia tournefortii and Kochia prostrata. Because of their valuable nutrients, and chemical composition, in arid and semi-arid regions they can act as alternatives to wheat straw and dry hybrid straw and help maintain livestock, such as Baluchi sheep (Bashtani 2017). To feed the increasing nourishment needs of the world, different actions are adapted in various countries, e.g., India (Kashyap et al. 2020), Vietnam (Paik et al. 2020), China (Nadeem et al. 2020), Italy (Incrocci et al. 2020), Tunisia (Bani et al. 2020) and Oman (Al-Farsi et al. 2020) to find novel solutions to manage, adapt and improve tolerance of various crops against salinity conditions.

\subsubsection{Saline Agriculture}

Saline soils and water are being used in Iran for saline agriculture (Khorsandi 2016). This concept and related techniques such as biosaline agriculture, seawater agriculture, haloculture, haloengineering and halophyte farming, are also being increasingly adopted in Iran. These, along with other methods to combat salinity, offer a range of benefits such as producing sustainable and economic products, erosion control, land reclamation, environmental quality improvement and improving the socio-economic status of local communities; they are in line with the objectives of the Water-Energy-Food Nexus concept, and take into consideration basic human needs (Khorsandi and Siadati 2017).

The feasibility of halophytic plants as new crops was examined for the first time in Iran through the international project (i.e., INT/5/144 "Sustainable Utilization of Saline Groundwater and Wastelands for Plant Production") (Khorsandi and Siadati 2017). The foundations of haloculture were initiated with the first "biosaline agriculture" research project in Iran (Pedraza 2009). The general principles of haloculture according to the capacities, conditions and needs of Iran are summarized in Figure 9.5.

Because of its range of agro-climatic environments, Iran has a rich genetic diversity of flora, fauna and microorganisms for economic haloculture under different saline situations in a diversity of geographical settings. One example is a successful program of halophytic tree cultivation in the highly saline lands of the Chah Afzal Area, Yazd Province (Khorsandi 2016; shown in Figure 9.6). The generation of energy and management of water are two of the critical activities that occur with haloengineering. Reducing dependency on fossil fuels and on the limited freshwater resources of the country are two goals that could be achieved (Khorsandi 2016; Khorsandi and Siadati 2017). 


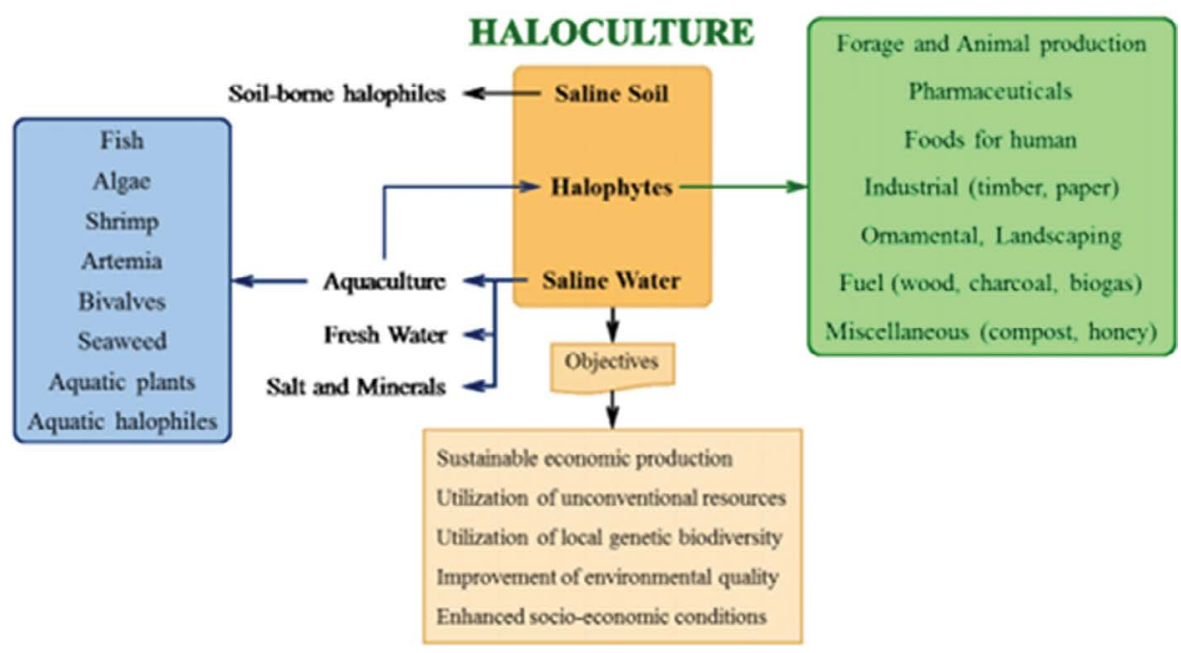

FIGURE 9.5 General view of haloculture principles and objectives. (Source: Khorsandi 2016.)

A review of literature (Ranjbar and Pirasteh-Anosheh 2015) has shown that halophytes studies began in the last half-century but have substantially increased since 2001. The research focus has been mainly on Kochia scoparia, Portulaca oleracea, Chenopodium album, Chenopodium quinoa and Salicornia spp.

Quinoa (Chenopodium quinoa) from the Amaranthaceae family is a discretionary halophyte and is classified as a pseudo-cereal. The cultivation and growth of

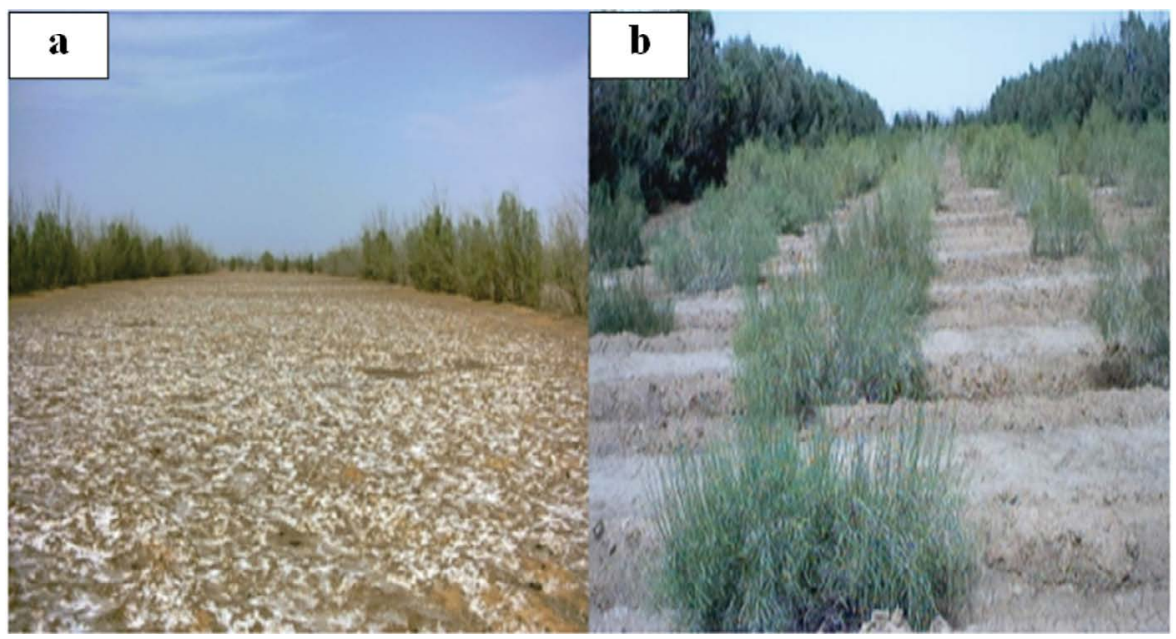

FIGURE 9.6 Haloculture services: (a) bare salty land, and (b) restored salty land using halophytes. (Source: Yazd Province, Iran; Khorsandi 2016.) 
quinoa under different conditions has occurred in European countries, the United States, Canada, Morocco, Pakistan and India. Quinoa has different mechanisms to survive salt stress. One of the exciting adaptations of this plant is the presence of salt bladder cells on leaf surfaces and panicles, which can absorb excess salt from the plant cells (Salehi and Dehghani 2019). Quinoa is currently cultivated in many parts of the world because of the value of quinoa seed and its high production potential in harsh environments (Khalili et al. 2019).

The cultivation of quinoa has been considered in Iran in recent years (Figure 9.7), where it is promising and resistant to saline conditions (Salehi and Dehghani 2019; Tavousi et al. 2018). This plant is cultivated in Iran in Sistan and Baluchestan, Khuzestan, South Kerman and Karaj provinces, which showed adaptation in November, late October, early October and the Middle of August, respectively (Tavousi et al. 2018). The main factors of this sound adaptation could be attributed to the appropriateness of temperature and precedent soil moisture. Seed yields of quinoa of $3 \mathrm{tha}^{-1}$ have been obtained under irrigation with saline water $\left(\mathrm{EC}_{\mathrm{w}} 14 \mathrm{dS} \mathrm{m}^{-1}\right)$ in Iran. Important selection issues for quinoa are photoperiod sensitivity, and salinity and drought tolerance, but the selection of better genotypes for different climates may be possible depending on the availability of sufficient genetic diversity. Quinoa genotypes have produced $4 \mathrm{tha}^{-1}$ under rainfed conditions (200 mm rainfall) (Salehi et al. 2018).

The initial establishment of quinoa is affected by irrigation water salinity, initial soil salinity, air temperature, soil oxygen and soil moisture. It is highly tolerant of salinity during germination and can germinate at $\mathrm{EC}_{\mathrm{e}}$ values up to $40 \mathrm{dS} \mathrm{m}^{-1}$. However, its susceptibility or tolerance to salinity depends strongly on cultivar.

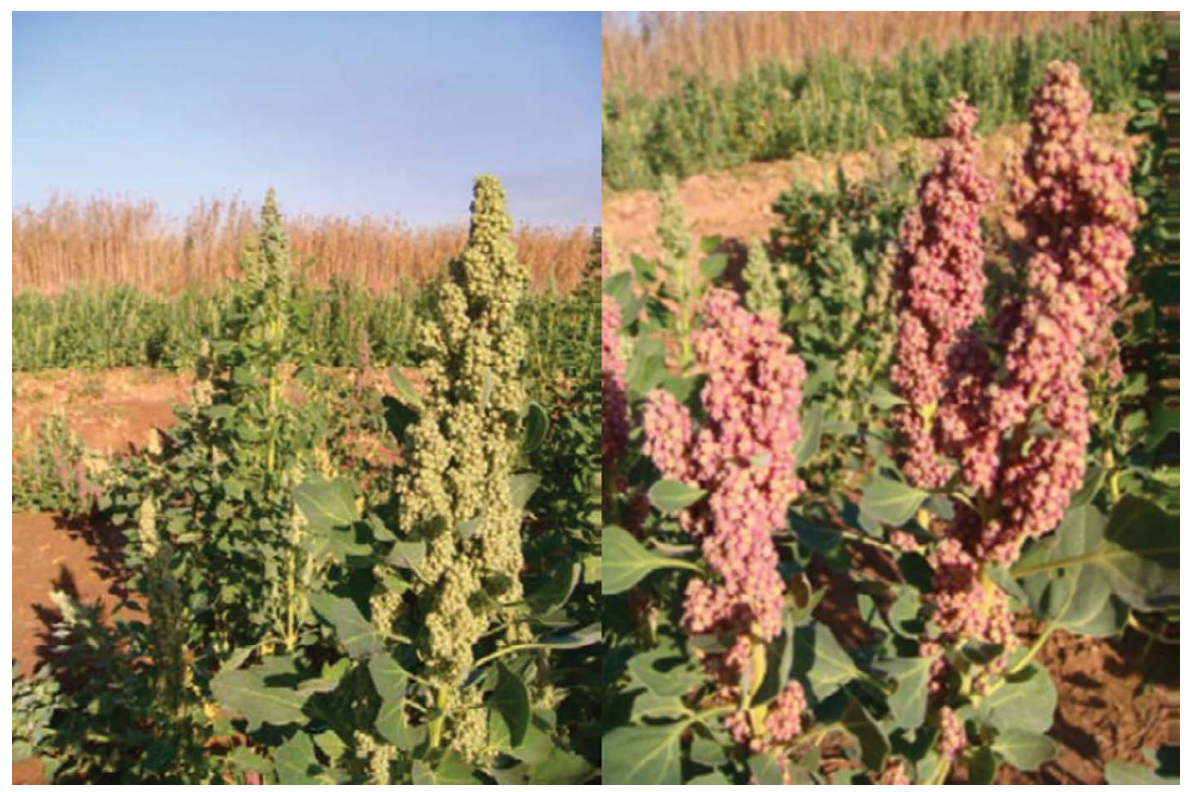

FIGURE 9.7 Quinoa at the pollination period. (Source: Tavousi et al. 2018.) 
Researchers have suggested suitable quinoa cultivars and appropriate areas for quinoa cultivation in the country (Tavousi et al. 2018; Salehi and Dehghan 2019; Bagheri 2019).

In order to examine the effect of electrical conductivity of water $\left(\mathrm{EC}_{\mathrm{w}}\right)$ and phosphorus levels on some of the characteristics of quinoa plant in greenhouse conditions, a factorial experiment was conducted by Khalili et al. (2019) in a completely randomized design with three replications. The results showed that increasing $\mathrm{EC}_{\mathrm{w}}$ to $15 \mathrm{dS} \mathrm{m} \mathrm{m}^{-1}$ (equivalent to $\mathrm{EC}_{\mathrm{e}} 30.4 \mathrm{dS} \mathrm{m}^{-1}$ ), decreased plant height by $18.65 \%$ and decreased panicle length by $52.4 \%$. When $\mathrm{EC}_{\mathrm{e}}$ values reached $183 \mathrm{dS} \mathrm{m}^{-1}$, the sodium concentration in the plants increased by $18.5 \%$ compared with the control. Increasing phosphorus application to the soil to $100 \mathrm{~kg} \mathrm{ha}^{-1}$ increased plant height by $12.3 \%$, increased panicle length by $8.8 \%$, and increased phosphorus concentration in shoots by $12.5 \%$, compared to the control. A comparison of the average interactions between salinity of irrigation water and phosphorus on plant height showed that a salinity of $3 \mathrm{dS} \mathrm{m} \mathrm{m}^{-1}$ increased plant height by $15.1 \%$, compared with the control. Adding phosphorus (100 kg per hectare triple-super phosphate) reduced the effect of salinity stress on the plant (Khalili et al. 2019).

Talebnejad and Sepaskhah (2018) conducted experiments over three years under greenhouse conditions with shallow saline groundwater in Fars Province, to determine the phenology, and responses of quinoa ("Titicaca, no. 5206") to salinity and water stress. Their findings suggested that quinoa could complete its growth cycle and generate a seed yield under Iranian conditions. With full irrigation $(800 \mathrm{~mm})$ there was a seed yield of $2.21 \mathrm{Mg} \mathrm{ha}^{-1}$; with a $70 \%$ decline in irrigation there was a $40 \%$ decrease in seed yield (to $1.16 \mathrm{~kg} \mathrm{~m}^{-3}$ ).

Akhani et al. (2003) described the Salicornia persica AKHANI sp. novo (Chenopodiaceae) from the central inland salt marshes of Iran in Esfahan, Fars and Yazd provinces. Zare and Keshavarzi (2007) conducted other research to identify the morphological characteristics of the Salicornieae (Chenopodiaceae) tribe native to Iran.

The Nanobiotechnology Research Institute has conducted a comprehensive plan on the ability of agricultural halophytes to produce forage, oil and other biological sub-products and prevent dust storms. Some important characteristics mentioned for the Salicornieae are including the possibility of irrigation with unconventional saline water and seawater (with a concentration of 27.734-33.281 dS m $\mathrm{m}^{-1}$ ) producing at least $15 \mathrm{t} \mathrm{ha}^{-1}$ dry fodder, a potential yield of $1.5 \mathrm{t} \mathrm{ha}^{-1}$ of high-quality edible oil, and a potential yield of 700-1800 $\mathrm{L} \mathrm{ha}^{-1}$ biofuel, application as a meal in poultry nutrition, productive employment creation, high salt storage capacity in aerial parts, saline soils emendation and potential application in bioremediation of heavy metals and petroleum contaminants from soil. Figure 9.8 shows some views of the Salicornieae produced in this project (http://www.abrii.ac.ir/en/).

\subsubsection{Executive Operations around Lake Urmia}

Lake Urmia (LU) is the one of the largest salt lakes in the world, and is located in northwestern Iran. The Lake Urmia Basin (LUB) has an area of $520 \mathrm{Mha}$, or $3.15 \%$ of the country, and supports a population of more than three million people. 

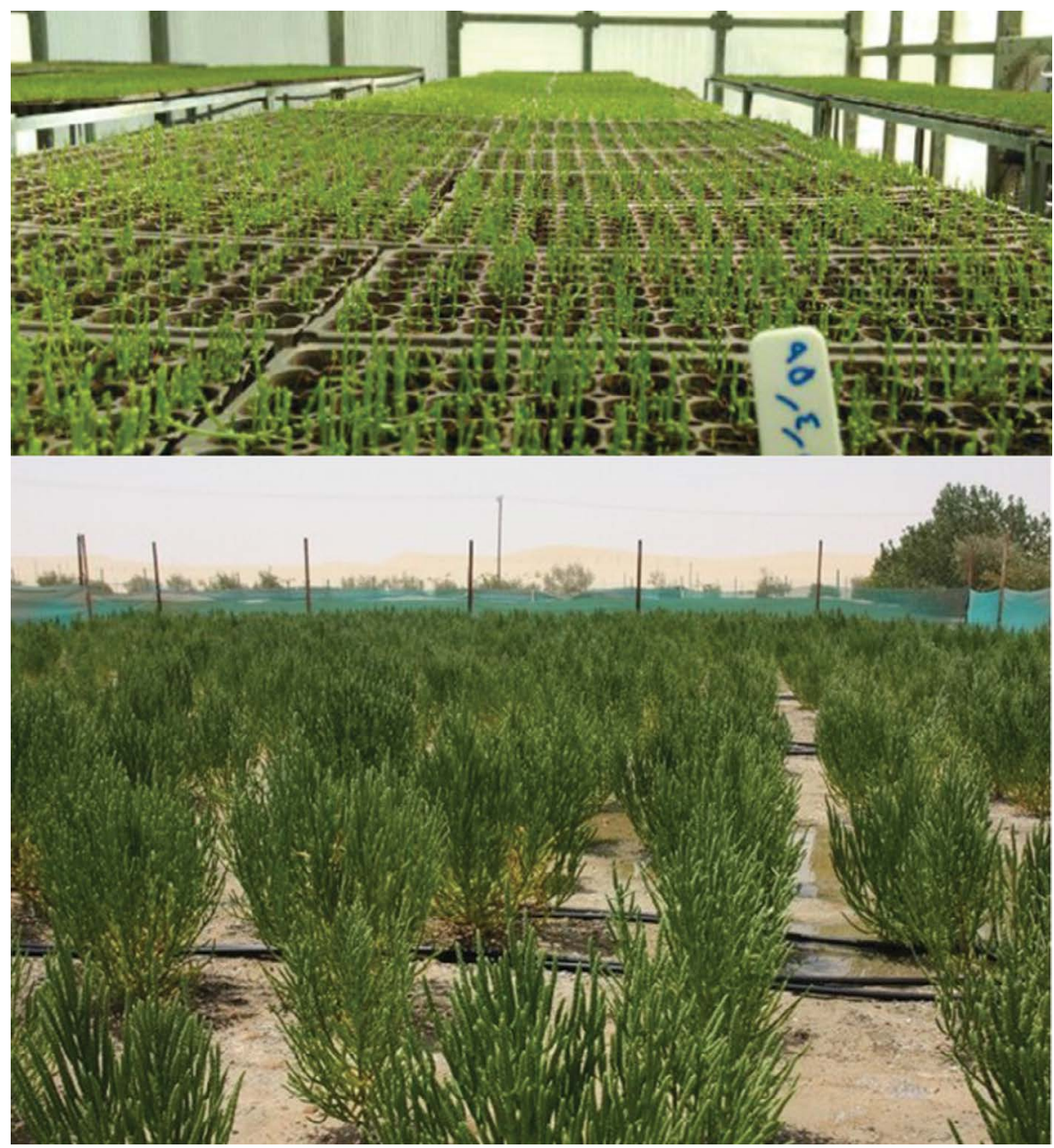

FIGURE 9.8 Implantation of superior Salicornia genotypes at the Nanobiotechnology Research Institute. (Source: http://www.abrii.ac.ir/en/.)

Fourteen permanent rivers provide the water ( 3.1 billion $\mathrm{m}^{3}$ annually) needed to maintain LU's water balance. Over the past two decades, unsustainable human activities have put increasing pressure on the natural resources of the LUB and the lake has decreased in size. Intensification of agricultural activities, the development of water resources and the destruction of natural resources, have increased salinity in the water to more than $300 \mathrm{~g} \mathrm{~L}^{-1}$; recent droughts have worsened the situation (Fanni and Maroofi 2017). The Urmia Lake Restoration National Committee (ULRNC; www.ulrp.ir) was founded in July 2013. It implemented measures during the years 2014 and 2015 to reclaim saline land and control the saline dust blowing off the lake. These measures have included the allocation of 55 billion Rials for 


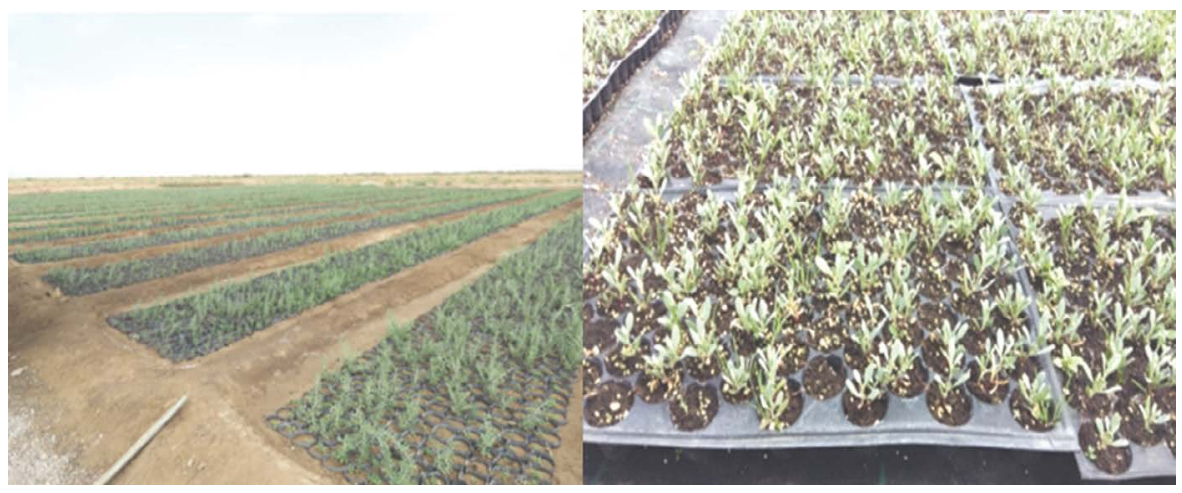

FIGURE 9.9 Production of Atriplex, Nitraria and Tamarix seedlings for planting in the areas around Lake Urmia. (Source: www.ulrp.ir.)

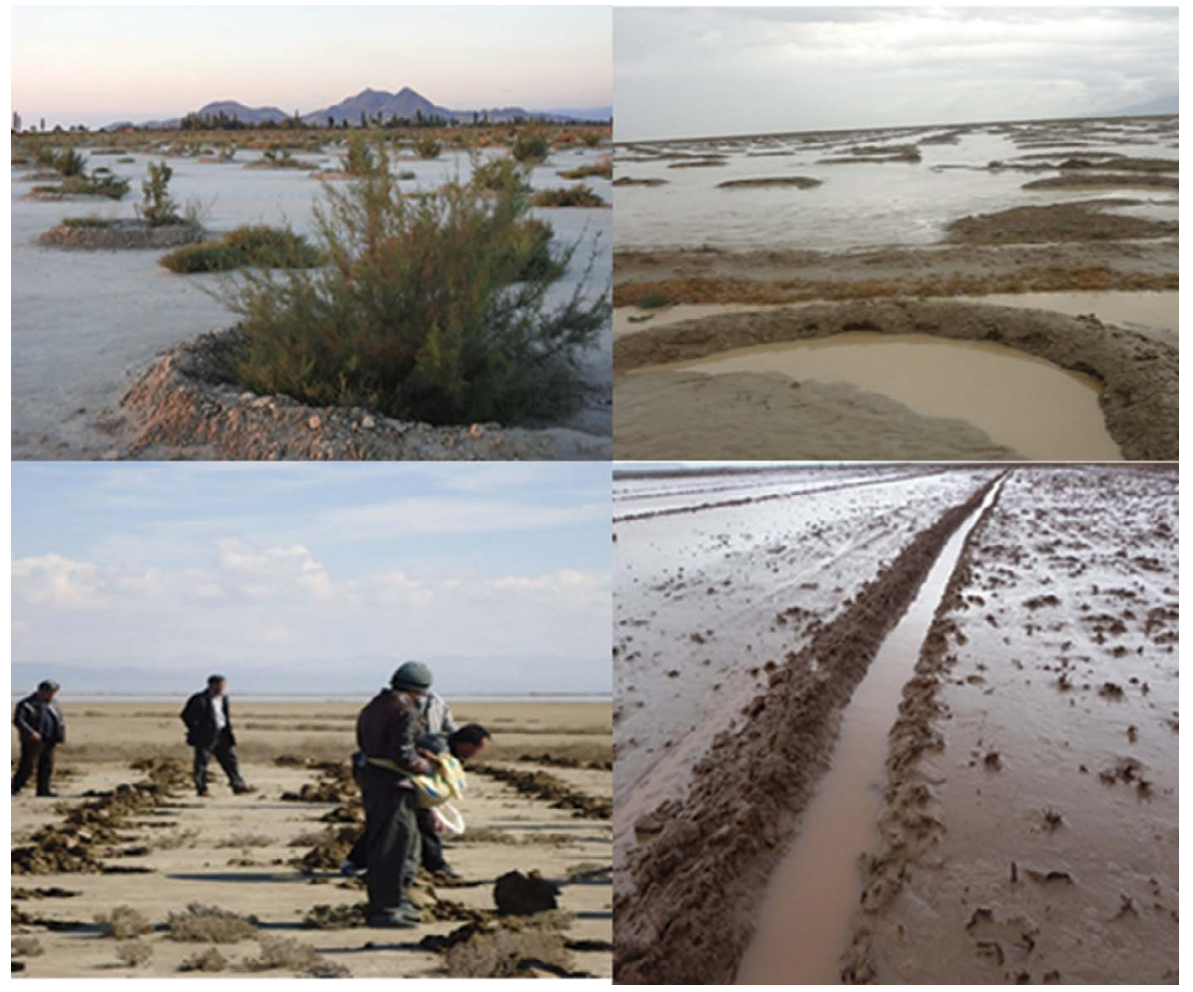

FIGURE 9.10 Surface runoff and sewage control operations in saline lands around Lake Urmia. (Source: www.ulrp.ir.) 


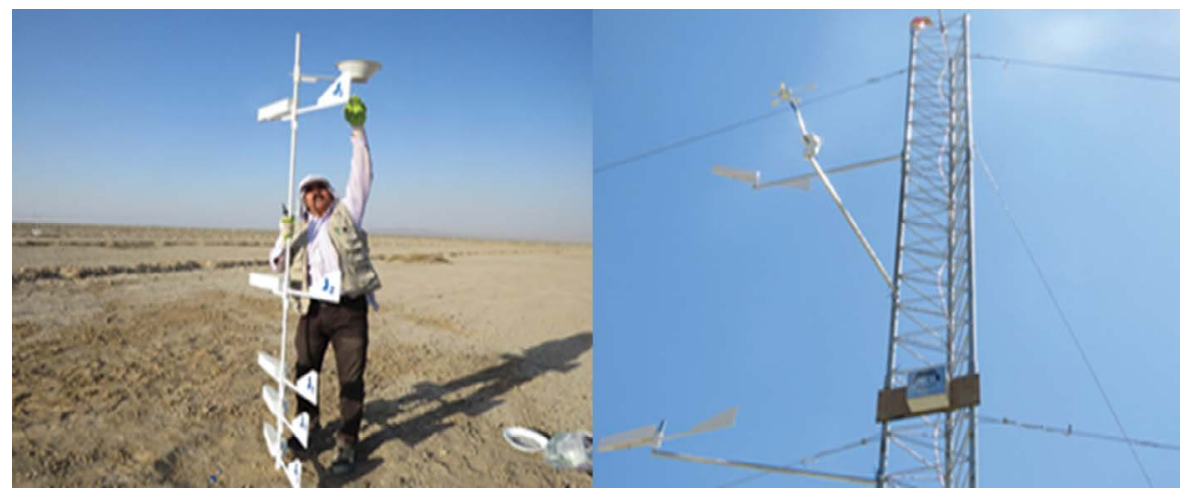

FIGURE 9.11 Construction of a quantification station of wind erosion and salt dust events. (Source: www.ulrp.ir.)

LUB restoration objectives, identifying critical areas and sites for geology and soil profiling operations on 7600 ha, combating desertification on 3200 ha using native species (Atriplex, Nitraria, Tamarix; Figure 9.9), improving surface runoff and sewage control operations (Figure 9.10). Land restoration processes and processes to increase plant cover have included the use of curved pits ( $150 \mathrm{ha})$, contour furrows (1450 ha) and pitting (1000 ha), seeding (2600 ha) and drainage channels (7500 m), the construction of windbreaks using Tamarix planting (528 ha), fence building (3200 ha), grazing management (200,000 ha) and the conservation of forests (300 ha). In addition, a new station to quantity wind erosion and salt dust events has recently been created. This station is equipped with sediment traps (set of three centralized and 64 decentralized traps) and can collect wind deposits at different altitudes (Figure 9.11).

\subsection{CONCLUSION}

We have discussed some of the crucial research conducted on the management of salt-affected lands in Iran. Table 9.1 summarizes the most important studies. The widely used management activities during the two last decades in Iran were leaching, drainage and irrigation water management, soil amendments application, haloculture, dry drainage, crop rotation systems and saline aquaculture. Use of best management practices (BMPs) in the management of salt-affected areas will be essential in ensuring sustainability and food security without compromising soil and water quality. The key to salinity management centers on assessing, managing and monitoring, whereby the efficiency of management options is monitored and assessed, and modifications are made consequently. Rational salinity management practices must allow for both environmentally and economically sustainable yields and for the restoration of soil and water health. The poor management of salt-affected resources in low-income countries is intrinsically linked to financial and managerial limitations and poor practices in situations of a changing climate, poor infrastructure and poor marketing arrangements. 
TABLE 9.1

Summary of Research Done on the Management of Saline Soil and Water Resources of Iran during the Period 2001-2020

\begin{tabular}{|c|c|c|c|c|c|c|c|}
\hline Year & Researcher/s & Approach & Case Study & Land Use & Texture & $\mathrm{EC}\left(\mathrm{dS} \mathbf{m}^{-1}\right)$ & Experiment Type \\
\hline 2002 & $\begin{array}{c}\text { Khoshgoftarmanesh } \\
\text { and Shariatmadari }\end{array}$ & Leaching & Qom Province & Agriculture & - & 67.1 & Field \\
\hline 2008 & Azadegan & Drainage and sulfur application & $\begin{array}{l}\text { Garmsar region, } \\
\text { Semnan Province }\end{array}$ & Orchards & $\begin{array}{l}\text { Loam-Clay } \\
\text { Loam }\end{array}$ & 8.9 & Field \\
\hline 2010 & Feizi et al. & Leaching & Isfahan Province & Agriculture & Clay & 7.7 & Field \\
\hline 2011 & $\begin{array}{l}\text { Yazdanpanah and } \\
\text { Mahmoodabadi }\end{array}$ & Amendments application and leaching & Kerman Province & Agriculture & Sandy Silty & $19 / 81$ & $\begin{array}{l}\text { Laboratory-Soil } \\
\text { column }\end{array}$ \\
\hline 2012 & Yazdanpanah et al. & Soil amendments & Kerman Province & Agriculture & Loam & 19.81 & $\begin{array}{l}\text { Laboratory-Soil } \\
\text { column }\end{array}$ \\
\hline 2015 & Feizi and Saadat & Irrigation management with salt water & Isfahan Province & Agriculture & Clay & 6.8 & Field \\
\hline 2015 & Saghafi et al. & $\begin{array}{l}\text { Rhizobacteria and saline water } \\
\text { application }\end{array}$ & Karaj, Alborz Province & Agriculture & Loam & 1.28 & Pot \\
\hline 2016 & Boostani et al. & $\begin{array}{l}\text { Rhizobacteria (PGPR) and Arbuscular } \\
\text { mycorrhizae fungi (AMF) } \\
\text { application }\end{array}$ & $\begin{array}{l}\text { North of Khuzestan } \\
\text { Province }\end{array}$ & Agriculture & $\begin{array}{l}\text { Silty Clay } \\
\text { Loam }\end{array}$ & 2 & Greenhouse \\
\hline 2016 & Khorsandi & Haloculture & $\begin{array}{l}\text { Chah Afzal, Yazd } \\
\text { Province }\end{array}$ & Agriculture & - & - & Field \\
\hline 2016 & $\begin{array}{l}\text { Mostafazadeh-fard } \\
\text { and Ghasemi }\end{array}$ & Dry drainage & Isfahan Province & Agriculture & $\begin{array}{l}\text { Sandy Loam } \\
\text { Clay }\end{array}$ & 3 and 7 & Laboratory \\
\hline 2017 & Ansari et al. & Dry drainage & Isfahan Province & Agriculture & Loam & 3 & Laboratory \\
\hline 2017 & $\begin{array}{l}\text { Bazzaneh and } \\
\text { Rezaie }\end{array}$ & Leaching & $\begin{array}{l}\text { Mahabad, West } \\
\text { Azerbaijan Province }\end{array}$ & Agriculture & Silty Clay & 8.438 .9 & Field \\
\hline 2017 & $\begin{array}{l}\text { Asadi Kapourchal } \\
\text { and Homaee }\end{array}$ & Crop rotation and leaching & $\begin{array}{l}\text { Ramhormoz, } \\
\text { Khuzestan Province }\end{array}$ & Agriculture & $\begin{array}{l}\text { Silty Clay } \\
\text { - Clay }\end{array}$ & $44-45$ & Field \\
\hline
\end{tabular}


TABLE 9.1 (Continued)

Summary of Research Done on the Management of Saline Soil and Water Resources of Iran during the Period 2001-2020

\begin{tabular}{|c|c|c|c|c|c|c|c|}
\hline Year & Researcher/s & Approach & Case Study & Land Use & Texture & $\mathrm{EC}\left(\mathrm{dS} \mathrm{m}^{-1}\right)$ & Experiment Type \\
\hline 2017 & Nasrollahi et al. & Drip irrigation with saline water & $\begin{array}{l}\text { Ahwaz, Khuzestan } \\
\text { Province }\end{array}$ & Agriculture & Silty Loam & 2.5 & Experimental site \\
\hline 2017 & Soltani et al. & Dry drainage & $\begin{array}{l}\text { Aburaihan Faculty, } \\
\text { University of Tehran }\end{array}$ & Agriculture & Loam & $5.1-7.4$ & Farm \\
\hline 2018 & Nakhaei et al. & Saline aquaculture & Kerman Province & $\begin{array}{l}\text { Water resources close to } \\
\text { agriculture and orchards }\end{array}$ & $\begin{array}{l}\text { Different } \\
\text { mainly with } \\
\text { high sand }\end{array}$ & $7.3-147.2$ & Field \\
\hline 2018 & $\begin{array}{l}\text { Hassantabar Shobi } \\
\text { et al. }\end{array}$ & Dissolved organic carbon application & Mazandaran Province & Agriculture & Clay & 13.85 & Incubation \\
\hline 2018 & $\begin{array}{l}\text { Talebnejad and } \\
\text { Sepaskhah }\end{array}$ & Quinoa cultivation & Fars Province & Agriculture & - & 20 & Greenhouse \\
\hline 2018 & Ansari et al. & Dry drainage & Isfahan Province & Agriculture & Loam & 3 & Laboratory \\
\hline 2019 & Rousta et al. & Humic Acid compounds application & Yazd Province & Agriculture & $\begin{array}{l}\text { Sandy Clay } \\
\text { Loam }\end{array}$ & 15.24 & Field \\
\hline 2019 & Moradi et al. & Organic carbon application & $\begin{array}{l}\text { Urmia, West } \\
\text { Azerbaijan Province }\end{array}$ & Agriculture & Sandy Loam & 0.58 & Pot \\
\hline 2019a & Sharifipour et al. & $\begin{array}{l}\text { Leaching and water and drainage } \\
\text { water application }\end{array}$ & $\begin{array}{l}\text { South of Khuzestan } \\
\text { Province }\end{array}$ & Agriculture & Clay & - & Field \\
\hline $2019 b$ & Sharifipour et al. & Drainage water management & $\begin{array}{l}\text { South of Khuzestan } \\
\text { Province }\end{array}$ & Agriculture & Clay & - & Field \\
\hline
\end{tabular}


Challenges in salinity research in Iran, include the absence of critical managerial initiatives such as a well-cleared strategic blueprint, a sound research foundation and a lack of teamwork. There will be an increased focus on "precision agricultural" approaches in the future.

\section{ACKNOWLEDGMENTS}

We warmly thank Dr. Farhad Khorsandi (Retired Professor of Soil Science, Islamic Azad University. Dārāb, Iran and independent research scientist) for the time he devoted to improve the final manuscript and for his valuable advices. We also extend our gratitude to the editorial team and anonymous reviewers for substantial comments on earlier version of this chapter.

\section{REFERENCES}

Akhani, H. 2003. Salicornia persica Akhani (Chenopodiaceae), a remarkable new species from Central Iran. Linzer Biologische Beiträge 35:607-612.

Al-Farsi, S. M., A. Nawaz, S. K. Nadaf, A. M. Al-Sadi, K. H. Siddique, and M. Farooq. 2020. Effects, tolerance mechanisms and management of salt stress in lucerne (Medicago sativa). Crop and Pasture Science 71:411-428.

Ansari, S., J. Abedi-Koupai, B. Mostafazadeh-Fard, M. Shayannejad, and M. R Mosaddeghi. 2019. Investigation of effect of dry drainage on the transport and distribution of cations using a physical model. Iranian Journal of Soil and Water Research 49(6):1215-1225.

Ansari, S., B. Mostafazadeh-Fard, J. A. Koupai. 2017. Soil salinity control under barley cultivation using a laboratory dry drainage model. International Drainage Workshop of ICID, Ahwaz., IRAN 4-7 March 2017, 398-404.

Asadi Kapourchal, S., and M. Homaee. 2017. Using desalinization models for scheduling crop rotation of saline-sodic soils: A case study in Ramhormoz Region, Iran. Journal of Soil and Water Resources Conservation 6(4):91-106.

Asch, F., and M. C. S. Woperei. 2001. Responses of field-grown irrigated rice cultivars to varying levels of floodwater salinity in a semi-arid environment, Field Crops Research 70 (2):127-137.

Azadegan, B. 2008. Effect of drainage and sulfur on quality improvement of saline and sodic soils of pistachio orchards in Garmsar. Irrigation and Drainage 2(1):55-62.

Bagheri, M. 2019. Handbook of Quinoa Cultivation. Seed and Plant Improvement Research Institute, Alborz, 47p.

Banaei, M. H., A. Moameni, M. Baybordi, and M. J. Malakouti. 2004. Iran Soils: New Transformations in the Identification, Management and Operation. Soil and Water Research Institute, Tehran, DC

Banakar, M. H., G. H. Ranjbar, and V. Soltani. 2012. Physiological response of some forage halophytes under saline conditions. Environmental Stresses Crop Sciences 5(1):55-65.

Bani, A., I. Daghari, A. Hatira, A. Chaabane, and H. Daghari. 2020. Sustainable management of a cropping system under salt stress conditions (Korba, Cap-Bon, Tunisia). Environmental Science and Pollution Research 1-8.

Banie, M. H. 2001. Soil Map of IRAN: Land Resources and Potentialities. Soil and Water Research Institute, Tehran, DC.

Bashtani, J. 2017. The importance of halophytes plants in animal nutrition. First National Congress of Haloculture, November 22-23, 2017, Yazd, 18 p. 
Bazzaneh, B., and H. Rezaie. 2017. Assessment of leaching of the salt-affected soils using different levels of pure and acidic water in selected regions of Mahabad irrigation and drainage Network. Applied Soil Research 5(1):104-114.

Boostani, H. R., M. Chorom, A. Moezzi, A. Karimian, N. Enayatizamir, and M. Zarei. 2016. Effect of plant growth promoting Rhizobacteria (PGPR) and Arbuscular Mycorrhizae Fungi (AMF) application on distribution of zinc chemical forms in a calcareous soil with different levels of salinity. Soil Management and Sustainable Production 6(1):1-24.

Corwin, D. L., J. D. Rhoades, and J. Šimůnek. 2007. Leaching requirement for soil salinity control: Steady-state versus transient models. Agricultural Water Management 90(3):165-180.

Debroy, S., T. Paul, and A. Biswal. 2020. Shrimp culture in inland saline waters of India: A step towards sustainable aquafarming. Food and Scientific Reports 1(4):84-88.

Dewan, M. L., and J. Famouri. 1964. The Soils of Iran. FAO, Rome, DC.

European Commission (EC): Communication from the commission to the council, the European Parliament, the European economic and social committee and the committee of the regions 2006. Thematic Strategy for Soil Protection, COM 231 Final, Brussels. https://eur-lex. europa.eu/legal-content/EN/TXT/PDF/?uri=CELEX:52006DC0231\&from=EN

Fanni, Z., and A. Maroofi. 2017. The drought's effects of Urmiyeh Lake on natural and human disasters/vulnerability of peripheral areas. Environment 2(57):1-16.

Fathizad, H., M. A. H. Ardakani, H. Sodaiezadeh, R. Kerry, and R. Taghizadeh-Mehrjardi 2020. Investigation of the spatial and temporal variation of soil salinity using random forests in the central desert of Iran. Geoderma 365:1-13.

FAO. 2000. Global network on integrated soil management for sustainable use of salt-affected soils. Country Specific Salinity Issues-Iran. FAO, Rome. http://www.fao.org/ag/agl/ agll/spush/degrad.asp?country1/4iran (accessed July 20, 2020).

Feizi, M., M. A. Hajabbasi, and B. Mostafazadeh-Fard. 2010. Saline irrigation water management strategies for better yield of safflower ('Carthamus tinctorius' L.) in an arid region. Australian journal of crop science 4(6):408-414.

Feizi, M., and S. Saadat. 2015. The effect of irrigation management with salt water in a crop rotation period. Water and Irrigation Management 5(1): 11-25.

Filehkesh, I., and Y. Hashemi Nejad. 2017. Application of salty flood for restoration of saline- sodic lands, a pattern for increasing forage production in desert ranges (Case study: Barabad, Sabzevar). First National Congress of Haloculture November 22-23, 2017: Yazd, 10 p.

Gowing, J. W., and G. C. L. Wyseure. 1992. Dry-drainage, a sustainable and cost-effectible solution to water logging and salinization. Proceedings of 5th International Drainage workshop. Lahore Pakistan: ICID-CIID, 1992. 6.26-6.34.

Guo, H., F. Zeng, S. K. Arndt, J. Zeng, W. W. Xing, and B. Liu. 2008. Influence of floodwater irrigation on vegetation composition and vegetation regeneration in a Taklimakan desert oasis. Chines Science Bulletin 53:156-163.

Hassantabar Shobi, S., F. Sadegh-Zadeh, M. A. Bahmanyar, and B. Jalili. 2018. Reclamation of saline-sodic soil with clay texture using dissolved organic carbon. Soil Management and Sustainable Production 8(1):159-173.

Hawrot-Paw, M., A. Koniuszy, M. Gałczyńska, G. Zając, and J. Szyszlak-Bargłowicz. 2020. Production of microalgal biomass using aquaculture wastewater as growth medium. Water 12(1):106. https://doi.org/10.3390/w12010106

Hazbavi, Z., M. R. Hosseini, Khalili, B., Moghadam, R. Mostafazadeh, and A. Jafarpoor. 2019. Salinity issue in agriculture and solutions scoping study in Iran, September 10-13, 2019, Leeuwarden, the Netherlands, 1 p.

Hazbavi, Z., S. H. R. Sadeghi, M. Gholamalifard, and A. A. Davudirad. 2020. Watershed health assessment using the pressure-state- response (PSR) framework. Land Degradation and Development 31:3-19. 
Heydari, N. 2019. Water productivity improvement under salinity conditions: Case study of the saline areas of lower Karkheh River Basin, Iran. In: Multifunctionality and impacts of organic agriculture IntechOpen. doi: 10.5772/intechopen.86891.

Homaei, M. 2003. The Response of Plants to Salinity. Iranian National Committee on Irrigation and Drainage, Iran, DC.

Hooke, J. M., and J. Mant, 2002. Floodwater use and management strategies in valleys of southeast Spain. Land Degradation and Development 13:165-175.

Hussain, M. I., A. Muscolo, M. Farooq, and W. Ahmad. 2019. Sustainable use and management of non-conventional water resources for rehabilitation of marginal lands in arid and semiarid environments. Agricultural Water Management 221:462-476.

ICID (International Commission on Irrigation and Drainage). 2002. Irrigation and food production information about ICID network countries. http://www.icid.org/index_e.html (accessed July 20, 2020).

Incrocci, L., P. Marzialetti, G. Incrocci, A. Di Vita, J. Balendonck, C. Bibbiani, S. Spagnol, and A. Pardossi. 2019. Sensor-based management of container nursery crops irrigated with fresh or saline water. Agricultural Water Management 213:49-61.

Ivushkin, K., H. Bartholomeus, A. K. Bregt, A. Pulatov, B. Kempen, and L. De Sousa. 2019. Global mapping of soil salinity change. Remote Sensing of Environment 231: 111260.

Kashyap, P. L., M. K. Solanki, P. Kushwaha, S. Kumar, and A. K. Srivastava. 2020. Biocontrol potential of salt-tolerant Trichoderma and Hypocrea isolates for the management of tomato root rot under saline environment. Journal of Soil Science and Plant Nutrition 20:160-176.

Khalili, S., A. Bastani, and M. Bagheri. 2019. Effect of different levels of irrigation water salinity and phosphorus on some properties of soil and quinoa plant. Soil and Water Sciences 33(2):155-167.

Khorsandi, F. 2016. Haloculture: strategy for sustainable utilization of saline land and water resources. Iranian Journal of Earth Sciences 8(2):164-172.

Khorsandi, F., and S. M. H. Siadati. 2017. Haloengineering and its significant role in sustainable development of salt affected ecosystems. First National Congress of Haloculture, Yazd, November 22-23, 2017, Yazd:13 p.

Khoshgoftarmanesh, A. H., and H. Shariatmadari. 2002. Reclamation of bare saline soils by leaching and barley production. Paper presented at the 17th World Congress of Soil Science. August 14-21 2002, Bangkok, Thailand.

Kolahchi, Z., and M. Jalali. 2007. Effect of water quality on the leaching of potassium from sandy soil. Journal of Arid Environments 68(4):624-639.

Konukcu, F., J. W. Gowing, and D. A. Rose. 2006. Dry drainage: A sustainable solution to waterlogging and salinity problems in irrigation areas?, Agricultural Water Management, 83(1-2): 1-12.1

Koocheki, A. 1996. The use of halophytes for forage production and combating desertification in Iran. In Choukr-Allah, R: Malcom, C. V; Hamdy (eds) Halophytes and Biosaline Agriculture. A. Marcel Dekker. Inc., USA:263-274.

Koocheki, A. 2000. Potential of saltbush (Atriplex spp.) as a fodder shrub for the arid lands of Iran. In G. Gintzburger (ED.), Fodder shrub development in arid and semiarid zones (pp. 178-183).

Mahmoodi-Eshkaftaki, M., and M. R. Rafiee. 2020. Optimization of irrigation management: A multi-objective approach based on crop yield, growth, evapotranspiration, water use efficiency and soil salinity. Journal of Cleaner Production 252:119901.

Manaffar, R., N. Abdolahzadeh, G. MoosaviToomatari, S. Zare, P. Sorgeloos, P. Bossier, and G. Van Stappen 2020. Reproduction and life span characterization of Artemia urmiana in Lake Urmia, Iran (Branchiopoda: Anostraca). Iranian Journal of Fisheries Sciences 19(3):1344-1358. 
Moameni, A. 2011. Geographical distribution and salinity levels of soil resources of Iran. Soil Research 24(3):203-215.

Moameni, A., H. Siadat, and M. J. Malakouti. 1999. The extent distribution and management of salt affected soils of Iran. FAO global network on integrated soil management for sustainable use of salt affected soils. Izmir, Turkey, 5 .

Moameni A., and A. Stein. 2002. Modeling spatio-temporal changes in soil salinity and waterlogging in the Marvdasht Plain, Iran. In Paper presented at the 17th World Congress of Soil Science August 14-21 2002, Bangkok.

Moradi, S., M. H. Rasouli-Sadaghiani, E. Sepehr, H. Khodaverdiloo, and M. Barin. 2019. The role of organic carbon in the mineralization of nitrogen, carbon and some of nutrient concentrations in soil salinity conditions. Soil Management and Sustainable Production 9(3):153-169.

Mostafazadeh-Fard, B., H. Mansouri, S. F. Mousavi, and M. Feizi. 2009. Effects of different levels of irrigation water salinity and leaching on yield and yield components of wheat in an arid region. Journal of Irrigation and Drainage Engineering 135(1):32-38.

Mostafazadeh-Fard, B., and E. Ghasemi. 2016. Soil salinity control using dry drainage concept. International Journal of Advances in Science Engineering and Technology 3:68-71.

Nabhan, G. P. 1979. The ecology of floodwater farming in arid southwestern North America, Agro-Ecosystems 5(3):245-255.

Nadeem, M., Li, J. Yahya, M. Wang, M. Ali, A. Cheng, A. X. Wang, and C. Ma. 2020. Grain legumes and fear of salt stress: Focus on mechanisms and management strategies. International Journal of Molecular Sciences 20:799. https://doi.org/10.3390/ ijms20040799

Nakhaei, N., M. Ramin, L. Yazdanpanah, H. Naghavi, M. Masomi, A. Zeioddini, and M. Alizade. 2018. Identification the useless source of brackish waters for aquaculture in Kerman Province. Ministry of Jihad-e-Agriculture, Agricultural Research, Education \& Extension Organization, Iranian Fisheries Science Research Institute - Kerman Agricultural and Natural Resources Research and Education Center Project, Project No.: 4-54-12-89043: 49 p.

Nasrollahi, A. H., S. Boroomand Nasab, and A. R. Hooshmand. 2017. Management practices using of agricultural drainage water with drip irrigation for crop production and lands sustainability in arid and semi-arid areas. International Drainage Workshop of ICID, Ahwaz., IRAN 4-7 March 2017: (pp.607-616)

Ning, S. R, B. B. Zhou, Q. J. Wang, and W. H. Tao. 2020. Evaluation of irrigation water salinity and leaching fraction on the water productivity for crops. International Journal of Agricultural and Biological Engineering 13(1):170-177.

Paik, S., D. T. P. Le, L. T. Nhu, and B. F. Mills. 2020. Salt-tolerant rice variety adoption in the Mekong River Delta: Farmer adaptation to sea-level rise. PLoS ONE 15(3):e0229464. https://doi.org/10.1371/journal.pone.0229464

Qadir, M., A. S. Qureshi, and S. A. M. Cheraghi. 2008. Extent and characterisation of saltaffected soils in Iran and strategies for their amelioration and management. Land Degradation \& Development 19(2):214-227.

Ranjbar, Gh., and H. Pirasteh-Anosheh, 2015. A glance to the salinity research in Iran with emphasis on improvement of field crops production. Iranian Journal of Crop Sciences. 17(2):165-178.

Rhoades J. D., and A. Dinar. 1991. Reuse of agricultural drainage water to maximize the beneficial use of multiple water supplies for irrigation. In: Dinar A., Zilberman D. (eds) The Economics and Management of Water and Drainage in Agriculture. Springer, Boston, MA.

Rousta, M. J., K. Enayati, M. Soltani, F. Ghane, N. Besharat, and E. Neshat 2019. The effects of humic acid application on yield and yield components of wheat and some chemical properties of a saline-sodic soil. Soil Management and Sustainable Production 8(4):95-110. 
Sabzevar, A. D., and M. Khosroshahi. 2010. The effects of the use of low quality flood on desert area. Iranian Journal of Range and Desert Research 17(1):127-148.

Sadeghi, S. H. R., Z. Hazbavi, and M. Gholamalifard. 2019. Interactive impacts of climatic, hydrologic and anthropogenic activities on watershed health. Science of the Total Environment 648:880-893.

Saghafi, D., H. A. Alikhani, and B. Motesharezadeh. 2015. Effect of plant growth promoting rhizobia on ameliorating the effects of salt stress in canola (Brassica napus L.). Soil Management and Sustainable Production 5(1):23-41.

Salehi, M., and F. Dehghani. 2019. Guide to Planting, Growing, and Harvesting Quinoa in Saline Conditions. Journal of Agricultural Education, Tehran, DC.

Salehi, M., V. Soltani, and F. Dehghani. 2018. Research finding and development program of quinoa production under saline and low-yielding dryland of Iran. First National Congress of Haloculture, 22-23 November 2017, Yazd, 7p.

Sayyari, M., and S. Mahmoodi. 2002. An investigation of reason of soil salinity and alkalinity on some part of Khorasan Province (Dizbad-e Pain Region). 17th WCSS, (pp.14-21), August 2002. Paper No. 1981, Thailand.

Seydehmet, J., G. H. Lv, and A. Abliz. 2019. Landscape design as a tool to reduce soil salinization: The study case of Keriya Oasis (NW China). Sustainability 11:2578. doi:10.3390/ su11092578.

Sharifipour, M., A. R. Hooshmand, A. Naseri, A. Hassanoghli, and H. Moazed. 2019a. Effect of leaching method and water and drainage water application order on desalinization and desodification of heavy soils. Iranian Journal of Soil and Water Research. doi: 10.22059/ijswr.2019.286228.668273.

Sharifipour, M., A., Liaghat, A. Naseri, H. Nozari, M. Hajishah, M. Zarshenas, H. Hoveizeh, and M. Nasri. 2019b. Drainage water management of irrigation and drainage networks of south west Khuzestan. Iranian Journal of Soil and Water Research. doi: 10.22059/ ijswr.2019.274004.668107.

Sharifipour, M., H. Nozari, A. Liaghat, A. Naseri. 2017. Plan of reusing of effluent waters of irrigation and drainage Networks at West region of Karun River. First National Congress of Haloculture, November 22-23 2017, Yazd, 7 p.

Shiati, K. 1998. Brackish water as a source of irrigation: behavior and management of saltaffected reservoirs (Iran). In: 10th Afro-Asian Conf. Bali, Indonesia.

Siadat, H. 1998. Iranian agriculture and salinity. In Proc. Conf. New Technologies to Combat Desertification, October (pp. 12-15).

Siadat, H., M. Bybordi, and M. J. Malakouti. 1997. Salt affected soils of Iran: A country report. In International symposium on "Sustainable management of salt affected soils in the arid ecosystem, September, Cairo, Egypt.

Soleimani, R., and A. Najafifar. 2017. The effect of several transplanted halophyte species on soil salinity and sodium adsorption ratio. First National Congress of Haloculture, November 22-23 2017, Yazd, 8 p.

Soltani, M., A. Rahimikhoob, A. Sotoodeh Nia, and M. Akram. 2017. Evaluation of HYDRUS_2D software in simulating dry drainage. Water Research in Agriculture 31(4):595-607.

Stec, A. 2020 Water Resources. In: Sustainable Water Management in Buildings. Water Science and Technology Library, Vol. 90. Springer, Cham.

Talebnejad, R., and A. R. Sepaskhah. 2018. Quinoa: a new crop for plant diversification under water and salinity stress conditions in Iran. ISHS Acta Horticulturae 1190:101-106. doi:10.17660/actahortic.2018.1190.17.

Tavousi, M., Gh. Lotfali, and A. Aine. 2018. Quinoa cultivation and related research results. Agricultural Education Publication, Karaj, DC.

Wang, C., J. Wu, W. Zeng, Y. Zhu, and J. Huang. 2019. Five-year experimental study on effectiveness and sustainability of a dry drainage system for controlling soil salinity. Water, 11(1):111. https://doi.org/10.3390/w11010111 
World Bank. 2005. Islamic Republic of Iran; Cost assessment of environmental degradation. Report No. 32043-IR. http://documents.worldbank.org/curated/ en/401941468284096627/text/320430IR.txt (accessed July 20, 2020).

Wu, J., L. Zhao, J. Huang, J. Yang, B. Vincent, S. Bouarfa, and A. Vidal. 2009. On the effectiveness of dry drainage in soil salinity control. Science in China Series E: Technological Sciences 52:3328-3334. https://doi.org/10.1007/s11431-009-0341-8

Yazdanpanah, N., and M. Mahmoodabadi. 2011. Time monitoring of leachate quality during reclamation process of saline-sodic soil using soil column. Soil Management and Sustainable Production 1(1):1-22.

Yazdanpanah, N., S. Pazira, A. Neshat, and M. Mahmoodabadi. 2012. Effect of different amendments on some physical and chemical properties of a saline-sodic soil. Arid Biome Scientific and Research 2(1):83-97.

Zare, G., and M. Keshavarzi, 2007. Morphological study of Salicornieae (Chenopodiaceae) native to Iran. Pakistan Journal of Biological Sciences 10(6):852-860. 